\title{
An afterlife of a scholarly epic: Frazer's Golden Bough and Lewis's argument
}

\section{from myth}

Abstract: C.S. Lewis believed that Jesus Christ embodied, in historical fact, a mythic pattern of dying and rising exemplified by deities such as Balder and Osiris. Taken from James Frazer's Golden Bough, an enormously influential work of early anthropological scholarship, the idea of a generalized 'dying and rising' motif is now substantially outmoded. Resting specifically on the resemblance between that motif and the story of Christ, and not (unlike Tolkien's argument from myth) on the Gospel's general qualities as a story, Lewis's argument from myth thus presupposes an incorrect vision of actual ancient pagan religion. That shortcoming is not fatal, however. In contrast to Chesterton in the Everlasting Man (another formative influence), Lewis used an aesthetic or ideal, rather than a historical, conception of myth, which he carefully distinguished from the word's ordinary senses. Although Lewis did believe that ancient mythmakers worshipped 'dying and rising' gods, the core of his case is 'our' apprehension of a mythic quality in such stories and the Gospels, independent of the beliefs of ancient writers or hearers of myths. That conclusion should discourage overly sanguine appropriations of Lewis's arguments, which never developed into a general theory of mythology and, once the historicity of the 'dying and rising' motif is set aside, can be developed into a case much like Tolkien's.

In the remarks an atheist friend made beside a fire in 1926, C.S. Lewis first encountered an argument that would frame his understanding of Christianity's relationship to the pagan past. Some twenty-nine years later, he recounted the moment thus: "Rum thing," [my friend] went on, “All that stuff of Frazer's about the Dying God. Rum thing. It almost looks as if it had 
really happened once." ${ }^{1}$ Coming after his reading of G.K. Chesterton's The Everlasting Man, the 'impact' was 'shattering', more, it would seem, because it undermined Lewis's confidence in atheism than because it buttressed a still-absent conviction in Christianity. Lewis had already thought Jesus historical, 'but' (as he wrote at the time) thought 'all the other tomfoolery about virgin birth, magic healings, apparitions and so forth ... on exactly the same footing as any other mythology.'2 Now, 'If [my friend], the cynic of cynics, the toughest of the toughs, were not—as I would still have put it—“safe," where could I turn?"3 The argument was to become that buttress for Christian belief five years later, during a latenight conversation with J.R.R. Tolkien and Hugo Dyson. They convinced him, as he told Arthur Greeves by letter, that if I met the idea of sacrifice in a Pagan story I didn't mind it at all: again, that if I met the idea of a god sacrificing himself to himself (cf. the quotation opposite the title page of Dymer) I liked it very much and was mysteriously moved by it: again, that the idea of the dying and reviving god (Balder, Adonis, Bacchus) similarly moved me provided I met it anywhere except in the Gospels. The reason was that in Pagan stories I was prepared to feel the myth as profound and suggestive of meanings beyond my grasp even tho' I could not say in cold prose 'what it meant'.

${ }^{1}$ Surprised by Joy: The Shape of My Early Life (New York: Harcourt, Brace, and World, 1955), 223-24.

${ }^{2}$ Letter to Arthur Greeves on 18 October 1916, no. 45 in They Stand Together: The Letters of C.S. Lewis to Arthur Greeves (1914-1963), edited by Walter Hooper (London: Collins, 1979),

${ }^{3}$ Surprised by Joy, 224. 
Now the story of Christ is simply a true myth: a myth working on us in the same way as the others, but with this tremendous difference that it really happened ${ }^{4}$

That conversation is well known to Lewis's readers. So too is his conviction that myth 'at its best' reflects reality and not just the teller's fancy, that it can be 'a real though unfocused gleam of divine truth falling on the human imagination' ${ }^{5}$ Recent studies have compared his apologetic argument from myth to the ideas of various influential theologians and mythologists, ${ }^{6}$ but no one has, so far as I know, called that argument's intellectual underpinnings into question. From the beginning, one category, the 'dying and reviving god', took central place in Lewis's thinking about Christianity and myth. ${ }^{7}$ Lewis did not simply think, as Tolkien did, that the aesthetics or plot patterns typical of myth in general were realized in a manger in Bethlehem and in an empty tomb in Jerusalem - that the Gospel was a supremely good as well as a true story. He believed something much more specific: that a particular pattern, found long ago in the myths of such gods as Adonis, Osiris, Balder, and

\footnotetext{
${ }^{4}$ Letter to Arthur Greeves on 18 October 1931, no. 172 in Hooper (ed.), They Stand
} Together, 427. The quotation from the Hávamál in Dymer is reproduced in a footnote by Hooper: 'Nine nights I hung upon the Tree, wounded with the spear as an offering to Odin, myself sacrificed to myself.'

${ }^{5}$ Miracles: A Preliminary Study, 2nd ed. (New York: Collier Books, 1960), 133-34, n. 1.

${ }^{6}$ See esp. C. Stephen Evans, The Historical Christ and the Jesus of Faith: The Incarnational Narrative as History (Oxford: Oxford University Press, 1996), 47-79, P.H. Brazier, 'C. S. Lewis and Christological Prefigurement', Heythrop Journal 48 (2007), 742-75.

${ }^{7}$ Or 'dying and rising' god; Lewis also speaks of 'Death and Re-Birth'. These three variations all refer to basically the same motif, and I will use all three interchangeably —as indeed Lewis himself seems to have done. 
Bacchus, was enacted, in actual historical events, in the death and resurrection of Jesus Christ. ${ }^{8}$ As he put it in 'Myth Became Fact',

The heart of Christianity is a myth which is also a fact. The old myth of the dying god, without ceasing to be myth, comes down from the heaven of legend and imagination to the earth of history. ... We pass from a Balder or an Osiris, dying nobody knows when or where, to a historical person crucified (it is all in order) under Pontius Pilate. ${ }^{9}$

Lewis's version of the apologetic argument from myth — there are others, of which we will briefly discuss Chesterton's and Tolkien's-is complicated by the tension between his conception of myth in general and his understanding of the myth of the 'dying and rising' gods in particular. The former, as we shall see, is not bound to cultural or anthropological history. Lewis distinguished between the mass of oral and written tales about gods and heroes (that is, the Greek, Egyptian, Norse, and other mythologies) and certain stories he found particularly moving and profound. This latter subset, 'myths' in the deepest sense, allowed a direct experience (or so Lewis believed) of realities otherwise graspable, only in deadening abstraction, by the intellect. ${ }^{10}$ These properly mythic stories could be ancient or modern, and might not be experienced in their depth by everyone. It is just such a myth that, on Lewis's view, became embodied in human history in the death and resurrection of Jesus. At the same

\footnotetext{
${ }^{8} \mathrm{Cf}$. the discussion, with particular reflection on his conversion, in 'Religion Without Dogma?' in God in the Dock: Essays on Theology and Ethics, edited by Walter Hooper, which I have consulted in The Collected Works of C. S. Lewis: The Pilgrim's Regress, Christian Reflections, God in the Dock (New York: Inspirational Press, 1996), 388-89. 9 'Myth Became Fact', 343.

${ }^{10}$ Myth Became Fact', in God in the Dock (reprinted in Collected Works), 341-44, at 342-3.
} 
time, however, Lewis believed that the myths of death and rebirth enacted or taken up into the death and resurrection of Jesus really were something ancient pagans had believed in, before Jesus' day. Myth, in other words, is a thing we, its readers, discern or experience; but the specific myth behind the Gospels was something in fact experienced by ancient mythmakers, even if they did not fully grasp what they were saying. Here, however, Lewis falls afoul of a momentous scholarly shift: it is no longer nearly so obvious as it was in his day that ancient myth-makers had believed in 'dying and rising' gods whose stories looked anything much like the Christian Gospel.

Lewis took the idea of 'dying and rising' gods from James George Frazer's masterwork, The Golden Bough. A vast collection of folklore, The Golden Bough had first been published in 1890 in two volumes; with the completion of its twelve-volume third edition in 1915 and the publication of a supplement in 1937, it spanned well over five thousand pages. Begun in order to explain why the priest of Diana at Nemi in ancient Latium had been a slave who gained and lost his post by homicide, The Golden Bough offered an account of the origins of 'primitive' religion in the worship of magician-kings. ${ }^{11}$ As an atheist, Lewis had embraced Frazer's work, and, when he 'first seriously read the New Testament', he was (as he put it in Miracles) 'all agog for the Death and Re-birth pattern and anxious to meet a corn-king'. ${ }^{12}$ What he said while still a convinced atheist suggests,

\footnotetext{
${ }^{11}$ Frazer's own conception of his aim became more general over time: see, e.g., Sabine MacCormack, 'Magic and the Human Mind: A Reconsideration of Frazer's Golden Bough', Arethusa 17, no. 2 (1984), 151-76.

${ }^{12}$ Miracles, 113.
} 
however, only a general inspiration by Frazer's ideas, ${ }^{13}$ and his later apologetics did not engage too closely with Frazer's specifics, for good reason. 'Those anthropologists who are most hostile to our faith', he says in Reflections on the Psalms, trace the story of Jesus, like the story of Balder, to the "“the mind and experience, especially the agricultural experience, of early man"". ${ }^{14}$ Frazer himself averred that Christ was undoubtedly as historical as 'Mohammed, Luther, and Calvin'. Jesus had, he suggested, died in a real but accidental (or, if one prefers, providential) enactment of the 'dying and rising' pattern. His crucifixion was (perhaps) an enactment of a hypothetical Babylonian sacrifice of Marduk, by way of a hypothetical execution of Haman on Purim transferred (by hypothesis) to Passover and possibly overlapping with the Roman soldiers' execution (as an obscure martyrological text attests) of a 'king of the Saturnalia', which (Frazer hypothesised) might once have been celebrated in March. ${ }^{15}$

${ }^{13}$ In the Letter to Arthur Greeves on 12 October 1916, no. 44 in Hooper (ed.), They Stand Together, 135, Lewis sketches an evolution of religion out of fear of natural forces and assimilates Christ to various deified kings; the evolutionary pattern is shared with Frazer, as P.H. Brazer notes in C. S. Lewis-The Work of Christ Revealed, with a forward by Justyn Terry, C. S. Lewis: Revelation and the Christ, 2 (Eugene, Oregon: Pickwick, 2012), 198-99, but Lewis's conception of kingship is comparatively anaemic and, signally, as-yet without the dying-and-rising motif.

${ }^{14}$ Reflections on the Psalms (London: Fount Paperbacks, 1977 [1961]), 89.

${ }^{15}$ Frazer first advanced his conjectures on the crucifixion in the second edition (The Golden Bough: A Study in Magic and Religion, 2nd ed. (London: MacMillan, 1900), 3: 186-98); in the third edition, he relegated them to an appendix, with an initial note stressing that he believed Jesus a real historical person (Golden Bough, 3rd ed., part 6 [= vol. 9]: The 
These conjectures are little more robust than the Golden Bough's core. Frazer made out the priest of Diana at Nemi to be a personified Jupiter, the oak-tree spirit married to the Queen of Heaven, whose 'external soul' was contained in the titular golden bough, the mistletoe plucked by Aeneas before his descent to the underworld. ${ }^{16}$ Questioned, after publication of the second edition, by the folklorist Andrew Lang, that argument has since come in for devastating critique. ${ }^{17}$ Though it remains plausible that Vergil did intend an allusion to the cult of Diana in his golden bough, it is difficult, with a century's hindsight, to see how anyone can have believed Frazer's grand prehistorical reconstruction. ${ }^{18}$ Frazer's

Scapegoat [London: MacMillan, 1913], 412-23). An atheist with an abiding interest and regard for religion (J. G. Ackerman, James Frazer: His Life and Work [Cambridge: Cambridge University Press, 1987], 11), Frazer appropriated distinctly Christian language for his primitive paganism. The worshipper of the god-king slain in fire might say, to the sceptic or shocked man of piety (so Golden Bough, 3rd ed., part 4/1 [= vol. 5], Adonis, Attis, Osiris: Studies in the History of Oriental Religion [London: MacMillan, 1914], 189), "“We do not see him face to face, but every year he manifests his divine life afresh in the blossoms of spring and the fruits of autumn. We eat of his broken body in bread. We drink of his shed blood in the juice of the grape."”

${ }^{16}$ I elaborate on the summary at Golden Bough, 3rd ed., part 7/2 (= vol. 11), Balder the Beautiful: The Fire-Festivals of Europe and the Doctrine of the External Soul (London: MacMillan, 1913), 302-3. For Vergil's golden bough, see Aeneid 6.201-11.

${ }^{17}$ Andrew Lang, Magic and Religion (London: Longmans, Green, and Co., 1901), 205-23.

${ }^{18}$ On the priest of Diana, see now Carin Green, Roman Religion and the Cult of Diana at Aricia (Cambridge: Cambridge University Press, 2007), 147-84, who sees a genuine allusion to the cult at Nemi in the Aeneid; otherwise, Smith, 'When the Bough Breaks', History of 
sources included visitors under the Roman Principate, who saw, not a primordial grove, but a large and busy precinct beside a lake on which an emperor, the eccentric Gaius Caligula, had floated gigantic pleasure-barges. ${ }^{19}$ The elder Cato, writing as a historian, had credited the foundation of the temple to a Latin league at the dawn of the fifth century B.C. ${ }^{20}$ Drawn to the vision of primordial antiquity, Frazer dismissed Cato's report in favour of a late-imperial grammarian's commentary, which credited the cult to the hero Orestes, the son of Agamemnon. Though the mythological connection was doubtless of no historical value, the custom of murdering a priest simply had, Frazer averred, to be primordial. ${ }^{21}$ The procedure is virtually self-refuting: a cult too barbarous to have begun in historical times ought not have been continued during them, either. ${ }^{22}$ It is not just Frazer's interpretation of the cult at Nemi,

Religions 12, no. 4 (1973), 341-71. The criticisms of Edmund R. Leach, 'Golden Bough or Golden Twig?' Daedalus 90, no. 2 (1961), 371-87, are especially ferocious; for a more moderate view that does little to undermine Leach's substantive objections, see Mary Beard, 'Frazer, Leach, and Virgil: The Popularity (and Unpopularity) of The Golden Bough', Comparative Studies in Society and History, 34, no. 2 (1992), 203-24.

${ }^{19}$ We are not dealing with new discoveries: all of this information can be gleaned from Frazer's own encyclopaedic learning, in Golden Bough, 3rd ed., vol. 1, The Magic Art and the Evolution of Kings (London: MacMillan, 1911), 1-10. Green, Roman Religion, 3-70, offers a modern account of the site's history.

${ }^{20}$ Cato, Origines, fr. 36 Cornell, cited by Priscian, Institutiones grammaticae 4.21.

${ }^{21}$ The key text is Servius' commentary on Vergil's Aeneid, 6.136; the connection with Tauris is already attested in Strabo, 5.3.12. Golden Bough, 3rd ed., vol. 1, 10-11, 19-22.

${ }^{22}$ It is no wonder that Frazer's German contemporary Georg Wissowa, in a still-essential survey of Roman religion, rejected Frazer's speculations, despite his admiration for the 
therefore, that is now out of favour, but his method of proto-historical enquiry. Even if a historian still endorsed the division between 'primitive' and more enlightened stages of human history, it would be quite impossible to imagine, with the Victorian anthropologist, that traces of primordial human culture could be accurately teased out of the customs of later ages. ${ }^{23}$ Our sources - to modern eyes - tell us about the Romans of historical times, not about the 'primitive' human customs that underlie later civilization.

The idea of dying-and-rising gods has proven rather more resilient. An elaboration of the idea, then current, that the 'oriental' cults of Attis, Mithras, and so forth prepared the way for Christianity, it has retained a limited plausibility even with that model's weakening. ${ }^{24}$ The parallels that can be drawn between the various Near Eastern gods and the Jesus Christ of the canonical Gospels are nonetheless not so strong as Frazer's freewheeling method made them. Any resemblance — and the most recent scholarship still finds gods who died and returned — is

Scotsman's vast learning: Religion und Kultus der Römer, 2nd ed. (Munich: Beck, 1912), 248, n. 3. Wissowa's account of the cult of Diana at Nemi has its own shortcomings: Green, Roman Religion, 150-3.

${ }^{23}$ On anthropological primitivism, see Adam Kuper, The Reinvention of Primitive Society: Transformations of a Myth, 2nd ed. (London: Routledge, 2005), 3-19.

${ }^{24}$ The classic study from Frazer's day is Franz Cumont, Les Religions orientales dans le paganisme romain, 3rd ed. revised (Paris: Librairie Leroux), 1929; the second edition, of 1909, was translated into English as The Oriental Religions in Roman Paganism (Chicago: Open Court, 1911). The scale of the model's demise may be judged from the comments of Jaime Alvar Ezquerra, one of the few defenders of a coherent category of 'oriental' religions, in Romanising Oriental Gods: Myth, Salvation and Ethics in the Cults of Cybele, Isis, and Mithras, trans. Richard Gordon (Leiden: Brill, 2008), 383-421. 
limited and requires us to trace commonalities among gods very different in character and religious function, while a focus on parallels between 'oriental' cults and Christianity has yielded a clear vision neither of those cults' historical contours nor of their real relationship to the nascent Christianity that gained popularity throughout the Roman world in rough parallel with them. ${ }^{25}$ The category 'dying and rising god' now seems too narrow and too much shaped by Christianity to describe a diffuse array of rites and myths whose gods underwent many different kinds of disappearance and reappearance. ${ }^{26}$

Scholarship can be slow to trickle into popular discourse, and Frazer's conception of a more-or-less universal motif of the 'dying and rising' god lives on in journalistic commentary, cultural criticism, and atheist polemics. ${ }^{27}$ Yet the spell that bewitched the young Lewis has been broken. To be 'agog for the Death and Re-birth pattern' would now savour of

\footnotetext{
${ }^{25}$ Alvar, Romanising Oriental Gods, 417-21. For a modest and learned defence of the category, see the widely praised study by Tryggve N. D. Mettinger, The Riddle of
} Resurrection: "Dying and Rising Gods" in the Ancient Near East, Coniectanea biblica, Old Testament series 50 (Stockholm: Almqvist \& Wiksell International, 2001).

${ }^{26}$ See the comments of David Frankfurter on Mettinger, Riddle, in Bryn Mawr Classical Review 2002.09.07, J.Z. Smith, 'Dying and Rising Gods', Encyclopedia of Religion, edited by Lindsay Jones, 2nd ed., vol. 4 (Macmillan Reference USA, 2005), 2535-40.

${ }^{27}$ See, e.g., Frank Fisher, 'Something to Chew On', The Guardian, 24 March 2008 (https://www.theguardian.com/commentisfree/2008/mar/24/somethingtochewon), Camille Paglia, Sexual Personae: Art and Decadence from Nefertiti to Emily Dickinson (London: Yale Nota Bene, 2001 [1990]), 53, or the Christ-mythicist Richard Carrier, 'Dying-andRising Gods: It's Pagan, Guys. Get Over It.', 29 March 2018, https://www.richardcarrier.info/archives/13890. 
anachronism, of a failure to appreciate genuine advances in understanding ancient cultures. A modern restatement of Lewis's version of the argument from myth would thus have to take a conditional, if not contrafactual, form. There were tales of dying and rising gods, of a sort; and if one finds sufficient resemblance between them and Christ to think that they could be related, then one might suppose that the myth-makers had glimpsed the moral and theological pattern that Christ would truly embody.

We can be sure that the myths' ancient readers, at least, did not generally embrace Christ as the fulfilment of their spiritual hopes. Many senators in fourth-century Rome enrolled themselves in the highest ranks of the cults of Mithras, Hecate, Bacchus, Ceres, Isis, and Attis. ${ }^{28}$ Their Christian critics were the ones who drew the analogies between Christ and the gods, not to cajole them into converting to something they believed already, but to condemn their worship for aping the truth. A few ante-Nicene apologists had found in resemblances to Christian cult and vocabulary a diabolical counterfeit of the religion adumbrated in the prophets and revealed in Christ. ${ }^{29}$ The one who developed the argument into a full-scale polemic was Julius Firmicus Maternus, an ex-astrologer, Sicilian, and minor senator who enjoyed good connections with the Roman élite under Constantine and his sons. ${ }^{30}$ When he urges pagan readers to embrace Christ as true bridegroom or to eat from his bread and cup, not that of Attis, we may suppose that his pagan targets, dwelling in Rome in

${ }^{28}$ See now Mattias Gassman, Worshippers of the Gods: Debating Paganism in the FourthCentury Roman West (Oxford: Oxford University Press, 2020), 76-106.

${ }^{29}$ Justin, Apologia I 54, 62, 64, Tertullian, De praescriptione haereticorum 40.

${ }^{30}$ His two extant works are the eight-volume astrological Mathesis and De errore profanarum religionum. For an overview focused mostly on the latter, see Gassman, Worshippers of the Gods, 48-75. 
the 340s, could see similarities between what they believed and what Christians did. The greatest of the senatorial devotees, Vettius Agorius Praetextatus, is said by Jerome to have jested that he would become a Christian, if only he could be bishop of Rome. ${ }^{31}$ Theological resemblances, if he admitted any, had not moved him. Praetextatus' refusal of the new religion seems to have been typical. The anonymous polemicist now known as 'Ambrosiaster' reported the scorn of pagan 'nobles' for Christians, while Augustine, informed by a well-placed clerical contact in Milan, makes devotion to the Egyptian gods the mark of the lofty pagan aristocracy of mid-fourth century Rome. ${ }^{32}$ The convert of whom he tells, the eminent rhetorician Marius Victorinus, was won over by reading Scripture and Christian books; his familiarity with Platonist teachings was presumably also important, as it later was for Augustine himself, but Augustine does not hint at a role for Victorinus' earlier religious devotion. ${ }^{33}$

Of course, Lewis knew that his ancient apologetic counterparts had condemned pagan cults and stories about pagan gods, and acknowledged, as any Christian might, that there was a 'diabolical' element in ancient myths. ${ }^{34}$ His arguments can accommodate such differences

\footnotetext{
31 Jerome, Contra Iohannem 8. Praetextatus' epitaph, erected by his wife, the vocal and
} forceful Fabia Aconia Paulina, celebrates his many priesthoods and wide learning: Corpus Inscriptionum Latinarum VI 1779.

${ }^{32}$ Ambrosiaster (here, pseudo-Augustine), Quaestiones Veteris et Noui Testamenti 114.9, 13; Augustine, Confessiones 8.2.3.

${ }^{33}$ Confessiones 8.2.4, on which see Stephen Andrew Cooper, Marius Victorinus' Commentary on Galatians, Oxford Early Christian Studies (Oxford: Oxford University Press, 2005), 19-20.

${ }^{34}$ Reflections, 89. 
from his own high view of the 'dying and rising' gods and of other myths he found similarly moving. His instinct, alerted by Frazer, for similarities between the Christian and pagan stories is not entirely divorced from ancient precedent, either. A Christian such as Firmicus Maternus could see that the burial, mourning, and exhumation of an (unnamed) 'god-who-issaved' did look rather like the biblical story of Christ. ${ }^{35}$ That was polemic, however, and it is doubtful whether any devotee of such a god was led to Christianity by observation of the resemblances between his stories and the Christian one. It is, at any rate, not a mode in which either pagans or Christians regularly wrote (and presumably also spoke) about the gods. If Lewis's apologetic argument from myth is construed as a claim about what particular gods or myths meant to the ancient people who believed in them, it becomes shakiest precisely where it is most nearly subject to empirical testing.

\section{Myth between history and personal experience}

Critique of this narrowly historical kind hardly exhausts the matter, since it is here that we face the tension between Lewis's views on myth and his specific arguments about the 'dying and rising' gods. On the one hand, Lewis's belief that 'dying and rising' is a motif common to the myths of Attis, Osiris, Balder, and the like, and that those gods are to be treated as a single category, is unmistakably a product of his reading of Frazer and of Frazer's influence on learned British circles in the early to mid-twentieth century. As we can now see, a singular 'dying and rising' motif is a distortionary oversimplification, invented in Lewis's own day, of a looser array of mythological patterns. Lewis, however, thought it a category inherent in the myths themselves, evident on some level to pre-Christian readers and in fact allowed by

${ }^{35}$ De errore profanarum religionum $22,24.1$, the latter framing a spectacular set-piece on the Passion, Resurrection, and Ascension. 
divine providence as a preparation for the Christian Gospel. He puts this idea most clearly in the lecture 'Religion Without Dogma?':

But if my religion is true, then these stories may well be a praeparatio evangelica, a divine hinting in a poetic and ritual form at the same central truth which was later focussed and (so to speak) historicised in the Incarnation. ${ }^{36}$

In Miracles, likewise, Lewis suggests that 'the truth first appears in mythical form and then by a long process of condensing or focusing finally becomes incarnate as History'. Lewis is speaking specifically of Hebrew 'mythology', whose choosing 'by God to be the vehicle of the earliest sacred truths' is 'the first step in that process which ends in the New Testament where truth has become completely historical'. Before this 'first step' in the process of 'focusing' must lie, therefore, an unfocused beginning; and indeed it is in the best of human myths that Lewis finds 'a real though unfocused gleam of divine truth falling on human imagination'. ${ }^{37}$ Pagan myths are prior to the Old Testament, and certainly to the Newexactly what someone who accepted Frazer's basic conclusions, though no longer his atheistic rejection of Christianity, would have taken for granted..$^{38}$ Lewis did not believe himself to be talking simply about what his contemporaries found in the myths, but about what ancient people, too, would have experienced in telling or hearing them.

On the other hand, Lewis does not put any stress on the antiquity of the myths of 'dying and rising' gods as such. His argument is fundamentally literal, not historical, and is overtly occasioned, in his own experience and often in the apologetic context of his works, by

\footnotetext{
36 'Religion Without Dogma?', 389.

${ }^{37}$ Miracles, 133-4, n. 1.

${ }^{38}$ Cf. also Reflections on the Psalms, 89-91, where Lewis consistently speaks of myth and myth-makers in the past tense and associates them with "'Pagan 'mysteries"”,
} 
the challenge of atheist appropriations of Frazer's ideas. He does not set out to show, in minute philological or archaeological detail, that Christianity works themes from earlier religions into a more convincing whole. Instead, he argues, briefly and usually with a certain impressionism, that Christianity embodies, in the facts of datable past events, the realities of nature, man, and God that had only been adumbrated in the myths. In practice, therefore, the historicist assumptions inherited from Frazer matter less than Lewis's own conception of myth, in which a story's import is experienced by the properly attuned reader, quite apart from the context in which it was first told or even the precise genre and form in which it might happen to be handed down. ${ }^{39}$

For Lewis, I would suggest, the myth of the 'dying and rising' god is fundamentally the same kind of thing as any other myth: a particularly moving, 'numinous' narrative that can be fully apprehended only by direct experience, not analysis. ${ }^{40}$ The fifth chapter of $A n$ Experiment in Criticism is especially thorough. Here, Lewis contrasts a synopsis of the myth of Orpheus, Aristotle's synopsis of the Odyssey, and a hypothetical synopsis (he refuses to make one) of a modern poem or novel. 'The first, though it is a bare outline, set down in the first words that came to hand, would, I believe, make a powerful impression on any person of sensibility, if he here met that story for the first time. ${ }^{41}$ That Vergil wrote about Orpheus

${ }^{39}$ As he puts it the preface to his edition of George MacDonald: An Anthology (New York: MacMillan, 1978 [1947]), xxvii, 'What really delights and nourishes me is a particular pattern of events, which would equally delight and nourish if it had reached me by some medium which involved no words at all—say by a mime, or a film.’

40 'Myth Became Fact', 343-4. 'Numinous': An Experiment in Criticism (Cambridge: Cambridge University Press, 1961), 44.

${ }^{41}$ Experiment, 40-41. 
matters not at all, and, though one can hardly avoid the name 'myth', 'that word is in many ways unfortunate' - as one might suppose, since Lewis questions whether the Odyssey itself is a myth in the way he intends. Neither the etymological sense of mythos (as Lewis remarks, 'any sort of story') nor an anthropological category of 'myths' matches what he means.

Most of them, whatever they may have meant to ancient or savage man, are to us meaningless and shocking. ... Out of this rank and squalid undergrowth the great myths_-Orpheus, Demeter and Persephone, the Hesperides, Balder, Ragnarok, or Ilmarinen's forging of the Sampo-rise like elms.

Equally, some modern stories are myths in Lewis's sense (he names Kafka's The Castle, with others, including 'the Ents and Lothlorien in Professor Tolkien's Lord of the Rings'). ${ }^{42}$ 'Myth', which we might almost capitalize, is thus an aesthetic category, or even, we might say, an ideal one. ${ }^{43}$ Although the story's outline or most famous tellings may be ancient, discerning what is 'myth' is not a historical or anthropological task. It is the special prerogative, not of the student of old or foreign things, but of the properly sensitive reader, who is prepared to experience the story and so to perceive, if not explain, its meaning.

${ }^{42}$ Experiment, 42-43; cf. George MacDonald, xxviii.

43 'Idea', implying eternality or at least transcendence, will perhaps seem the wrong word to the philosophically precise; I mean it in much the loose way Lewis himself did when he tried to describe what attracts the reader again to a story that rests on surprise ('a certain ideal surprisingness', in 'On Stories', Essays Presented to Charles Williams, edited by C.S. Lewis (Oxford: Oxford University Press, 1947), 90-105, at 102-3). Cf. 'Myth', 343, and Brazier, 'Christological Prefigurement', 760-1; I doubt, however, pace Brazier, that there is anything Platonic about this idealism: n. 72, below. 
This conviction animates Lewis's apologetic argument from the myths of 'dying and rising' gods. He roots the argument not in specific ancient accounts of divine dying and rising, which he never so much as cites, but in the connections that he can trace, as a reader, between the myths - always articulated in a general form — and the Gospel or the natural world. ${ }^{44}$ This method receives its most elaborate statement in Miracles. Here, Lewis describes the process by which the myth-makers arrived at their apprehension of the divine truth. Before his conversion he had, he explains, expected Jesus to be a 'corn-king', a god who would enact the cyclical dying and rising of plants through his own death and rising, and was disappointed. Jesus fit the part, even spoke of bread as his body, yet gave no hint of knowing he was a corn-king. The explanation Lewis found in theology: 'the one true God' is 'the God of Nature', and so 'He is constantly doing all the things that Nature-Gods do: He is Bacchus, Venus, Ceres all rolled into one.' Yet being above nature, 'He is not a nature-God'. Thus, 'the Corn-King is derived (through human imagination) from the facts of Nature, and the facts of Nature from her Creator' ${ }^{45}$ In this indirect way, the corn-king becomes an image of God himself, who is 'Nature's Original' ${ }^{46}$ Pagan myth, reflecting a certain pattern found in the order of nature, beyond the specific, contingent development of any particular pagan religious tradition, thus indirectly and imperfectly reflects the nature of God himself, which has become supremely visible in Christ.

\footnotetext{
${ }^{44}$ Perhaps it is this at which Evans, Historical Christ, 56, is aiming when he says, 'Lewis claims both that the Gospel has the form of myth and that it has parallels in other myths, but these two claims are logically distinct.'

${ }^{45}$ Miracles, 113-16.

${ }^{46}$ Miracles, 115-16.
} 
The parallel between Christ and the dying-and-rising gods is, as Lewis articulates it, neither simply a sign that the Gospels had borrowed from pagan mythology nor a revelation of the myth-makers' conscious perception of divine reality. They glimpsed something true about the world and so also about God. They will not, however, have grasped the full depth of what they were saying - the fact that they were talking about a singular Creator or (still more) that their redemption would proceed in the way it has. As Lewis argues elsewhere, a myth offers to its readers a direct experience of a reality not analysable in words, and it is only in the life of Christ that myth can be grasped as full 'historical fact' ${ }^{47}$ It was also so, we may infer, for the ancient makers of the myths, who did not know Christ or even the Hebrew prophets, in whom (as Lewis speculates in Miracles) myth was already beginning to enter history. For Lewis, these deeper layers are, though they lay beyond the first tellers' grasp, a genuine part of the myths' meaning. In the dying and rising god, he suggests in Reflections on the Psalms, as in the example of the tortured righteous man in Plato's Republic, there is a real instance of the pagan prefiguration that many Christians had found (probably wrongly, he admitted), in the prophecy of the child to be born in Vergil's Fourth Eclogue.

'In the sequence of night and day, in the annual death and rebirth of the crops, in the myths these processes gave rise to, in the strong, if half-articulate, feeling (embodied in many Pagan "mysteries") that man himself must undergo some sort of death if he would truly live, there is already a likeness permitted by God to that truth on which it all depends. ${ }^{48}$

\footnotetext{
47 'Myth Became Fact', 343-4.

${ }^{48}$ Reflections, 89-90 (in single quotation marks as the words of a Christian rebutting both anthropological critics of Christianity and Christian apologists hostile to the myths). On the
} 
Neither Plato nor the myth-makers understood what they were saying, but they, too, could have recognised, if (or, on Lewis's view of the afterlife, when) they had encountered the story of Christ, that here was the reality at which they had been aiming. 'One can, without any absurdity, imagine Plato or the myth-makers if they learned the truth, saying, "I see ... so that was what I was really talking about. Of course.” 49

As we have seen, we may doubt whether ancient pagans who believed the myths of Attis, Osiris, or Bacchus really did say any such thing upon hearing the Christian story. But Lewis's argument does not suppose that all should have, only that a reader properly attuned to the story could have grasped (or can now grasp) the resemblance. This belief helps to loosen, if not finally resolve, the tension with Lewis's Frazerian conviction of the antiquity of the 'dying and rising' gods. Although Lewis did think that ancient tellers of myths really did believe in corn-kings, he is not trying to reconstruct the actual beliefs of past peoples, but to trace within their stories a higher truth that they may only have grasped in shadow (which is to say, perhaps not consciously at all). Lewis's chief concern is therefore not with actual ancient paganism, with the details of ritual or the ordinary pagan's perception of the desires or beliefs his worship expressed. It is not even with ancient interpretations of myth. It is, instead, with the myths themselves - with the ways in which the myths, read in Christian hindsight, echo realities reflected in the natural order and now clearly revealed in the actions of God within human history.

Despite enormous differences of method, Lewis is taking up an ancient apologetic conviction anew. As one of the most sensitive modern readers of the most classicizing of

ancient Christian reception of the Sibylline Eclogue, see now Daniel Hadas, 'Christians, Sibyls and Eclogue 4', Recherches augustiniennes et patristiques 39 (2013), 51-129.

${ }^{49}$ Reflections, 91 (ellipses in original). 
ante-Nicene apologists, Lactantius, has put it, 'This [Christian] truth is so mighty that it pervades every aspect of reality, so that witness to it may be found in words which had a different end, in the mind of their original author, than the interpretation placed upon them by Lactantius. ${ }^{50}$ Lactantius, writing at the beginning of the fourth century, could even have agreed with Lewis on the philosopher's tortured wise-man, whom he takes as a figure for the Christian martyrs of his day. ${ }^{51}$ The difference is that Lewis, removed from active pagans by a millennium and a half, can view pagan myths and even mysteries with greater appreciation, and that he, a man of the early twentieth century with deep Romantic convictions, is more focused on 'Nature' than on the classical tradition that was all-authoritative for an educated fourth-century pagan.

The shifting of myth away from anthropological analysis and toward the reader's experience partially extricates Lewis's apologetic argument from myth from the kind of historicist critique I have suggested. Lewis's appreciation of the myths' power does not actually require ancient people to have realized that the gods they were worshipping fell into a coherent 'dying and rising' category. They need only have done rituals or told stories in which a sufficiently insightful modern reader can find the echoes of God's work in Creation, or in the redemption of mankind. The advantage of such an approach can be seen never more clearly than when Lewis's arguments are compared to an apology, profoundly influential on his own thinking, that does hinge upon the strict historical facts about Roman religion and mythology. Framed in its foreword as a corrective to H.G. Wells' popular survey, The

\footnotetext{
${ }^{50}$ Jackson Bryce, The Library of Lactantius, Harvard Dissertations in Classics (New York:
} Garland, 1990), 350.

${ }^{51}$ Diuinae institutiones 5.12.5-7, on Cicero's version of the wise-man in De re publica 3.13. 
Outline of History, The Everlasting Man takes aim at the folklorists, as well. ${ }^{52}$ Chesterton, who praises Andrew Lang, insists, against Frazer, not just on the imaginative value of mythology for the modern reader, but on grasping that, for the ancient hearer, too, the myth was a good story first. ${ }^{53}$

Against the early anthropologist's snobbery toward 'primitive' peoples, Chesterton makes a witty defence of the unity of human experience across time. As he puts it, "When Hiawatha was told by his nurse that a warrior threw his grandmother up to the moon, he laughed like any English child told by his nurse that a cow jumped over the moon." 54 However, Chesterton is not arguing simply that we, nowadays, ought to read with charity the myths told by peoples who may seem too foreign or primitive for our regard. He also uses his common-sense reading of mythology to sketch a cultural clash utterly vital, on his view, for understanding the trajectory of human history. This, of course, is the defence of Rome against Hannibal and destruction of Carthage in the Third Punic War. Evoking his earlier discussion

52 Thus, e.g., The Everlasting Man, People's Library Edition (London: Hodder and Stoughton, 1928 [1925]), 119, where Chesterton has both Frazer and Freud in his sights: 'The true origin of all the myths has been discovered much too often. ... Everything is phallic; everything is totemistic; everything is seed-time and harvest; everything is ghosts and graveofferings; everything is the golden bough of sacrifice; everything is the sun and moon; everything is everything.'

${ }^{53}$ Everlasting Man, 121.

${ }^{54}$ Everlasting Man, 117, 'A really fine work of folk-lore, like The Golden Bough, will leave too many readers with the idea, for instance, that this or that story of a giant's or wizard's heart in a casket or a cave only "means" some stupid and static superstition called "the external soul.", 
of mythology, Chesterton portrays genuine Latin religion as nature-cult, a worship of 'homely' and largely wholesome agricultural gods, though it sported a Greek veneer and hid a few 'uglier things underneath' (he names, of course, the cult of Diana at Nemi). ${ }^{55}$ To these sturdy peasants, the efficient, mercantile infanticide of Carthage was an abomination, and so they waged war against her to the bitter end. ${ }^{56}$ In that victory, Chesterton insists, Rome won though she had almost died, and all that was good from antiquity was passed down to us. ${ }^{57}$

This account, for all its evocative power, truncates and distorts real Roman religion and politics alike, and it does so by divining the attitudes of the common Roman from Chesterton's own imagination of what the Roman's myths meant. ${ }^{58}$ The foil for Chesterton's defence of Rome is Wells' invective against Cato, whose 'ruling passion seems to have been hatred for any human happiness but his own', and Wells' dour vision of Rome 'murdering Carthage' in the madness of the Punic Wars. ${ }^{59}$ Though Wells reported, rightly, that the

55 Everlasting Man, 165-6.

${ }^{56}$ Everlasting Man, 167-8.

${ }^{57}$ Everlasting Man, 174-6.

${ }^{58}$ It is also worth noting (though for our purposes less important) that Chesterton conflates Roman mythology and ritual practice, despite his grasp of the differences between philosophy about the gods and worship of the gods (Everlasting Man, 143-5, 270). In fact, all three were basically distinct cultural discourses, which experts could harmonize only with difficulty: see especially Cicero, De natura deorum 2.70, and Varro, Antiquitates rerum diuinarum fr. 7 Cardauns, quoted at Augustine, De ciuitate dei 6.5.

${ }^{59}$ The New and Revised Outline of History: Being a Plain History of Life and Mankind (Garden City, New York: Garden City Publishing, 1931 [first edition 1920]), 437-9; contrast Everlasting Man, 142: 'It is easy enough to make a merely harsh and inhuman figure either of 
Romans turned to human sacrifice in the third century B.C., Chesterton passes over the detail. ${ }^{60}$ One might allow him the omission, since the Romans offered human victims only under extraordinary duress, while the Carthaginians made infanticide a regular part of their religion, but it shows a flaw in Chesterton's moral fervour. ${ }^{61}$ His practical, mercantile Carthaginians were in fact not so very different from Cato, whose cruelty toward his slaves Wells acknowledged and whose special hatred for the ritual killing of babies is Chesterton's projection. ${ }^{62}$ Cato actually wished, according to the elder Pliny and Plutarch, to see Carthage destroyed in order to free Rome from the fear of its enemy. ${ }^{63}$

Elijah raving above the slaughter of Carmel or Cato thundering against the amnesty of Africa.'

${ }^{60}$ Outline, 436, 439, 451.

${ }^{61}$ Livy, 22.57, calls one famous example, the live interment of two Gauls and two Greeks following Hannibal's victories in 216, 'a rite hardly Roman' (minime Romano sacro). Celia E. Schultz, 'The Romans and Ritual Murder', Journal of the American Academy of Religion, 78, no. 2 (2010), 516-41, concludes (on p. 535), that the Romans had long found human sacrifice distasteful, but came only to reject it completely 'at the beginning of the last century BCE'. On Carthaginian infant sacrifice, see now Brent D. Shaw, 'Lambs of God: An End of Human Sacrifice', Journal of Roman Archaeology, 29 (2016), 259-91.

${ }^{62}$ De agri cultura 2: the pater familias should give ill slaves less food and sell the old or diseased. Cato comes in for Plutarch's rebuke on just this score at Vita Catonis Maioris 5.1-6. ${ }^{63}$ Historia Naturalis 15.20, Vita Catonis Maioris 27.3. 
A mirror for his localist, domestic England, Chesterton's imagined Rome also foreshadows his Christianity, likewise Roman, that has died five deaths and yet lives. ${ }^{64}$ That quasi-typological framework requires his Rome to be a historical, rather than a merely legendary, Rome. If he is wrong about its religion or its politics, his argument may be a plausible response, on the level of morality or sentiment, to Wells, to Frazer, and to his contemporaries who desired economic success above all else, but it will not make a rational case for Christian belief. Lewis's argument from myth is more resilient to such criticism. Plants spring up and die away, whether or not those who worshipped Attis or Osiris did in fact believe that their gods died and rose in time, or analogy, with the corn. In adapting Frazer, Lewis is, like Chesterton, appropriating for his apologetic what he takes to be the deeper meaning of myth. For his argument to work, however, all that is strictly necessary is to see the mythic power of the tale, its fitness to the shape of the natural order. We need not believe, with Chesterton, that Hiawatha 'laughed like any English child' at his nurserytales. ${ }^{65}$ The point, surely, is the brotherhood of the 'primitive' Iroquois and the 'civilized' Englishman, and so of the whole human race, but how should Chesterton have known what his people's stories meant to Hiawatha in what we call the sixteenth century? We can, however, believe in corn-kings and dying and rising gods, even if the worshippers of Attis did not, because we know about corn, about rebirth, and about death, with which all mankind must contend. The myth, because it points to a reality that arches over both ancient and modern culture, is not bound to the experiences of its ancient listeners.

${ }^{64}$ Everlasting Man, 290-303. For the political resonances, cf. Susan Hanssen, 'Rome in the historical imagination of G. K. Chesterton's Everlasting Man', Church, Communication and Culture 5, no. 1 (2020), 24-35, at p. 26.

${ }^{65}$ Everlasting Man, 117. 


\section{Reframing the argument from myth}

The detachment from the history of religions comes at a cost. The argument from myth risks becoming an argument from modern mythology, from what 'we', not 'they', find numinous and compelling. That both Lewis and many others, including luminaries of twentieth-century literature, did find such imaginative power in Frazer's Golden Bough cannot be doubted. ${ }^{66}$ In Lewis's own works, reflexes of Frazer appear even in the most unexpected places: the 'SkyFather' and 'Earth-Mother', joined in the "'Pagan sacrament"” of intercourse in The Four Loves, bear a distinctly Frazerian colour. ${ }^{67}$ They are enacting the divine union in 'ritual' or 'charade', in which they become for a moment, as it were, a god and a goddess-yet only for the ritual, and for the moment, and there is no question of magic or idolatry. Lewis may be a Frazerian, but he is a Christian Frazerian, neither denigrating such thinking as superstition nor holding the 'pagan' apart from God. Christianity, as he envisions it, is a religion at once 'Thick' and 'Clear'; it demands profession of a creed and 'an enlightened universalist ethic', as well as participation — indeed, while one participates, and as a prerequisite for participating - in a blood-mystery. ${ }^{68}$ As for Lewis's theology, so also and more resoundingly

${ }^{66}$ For aspects of that influence, see John B. Vickery, The Literary Impact of the Golden Bough (Princeton: Princeton University Press, 1973), 79-116, but note the reservations expressed by Charles Rossman in James Joyce Quarterly 11, no. 4 [1974], 420-23. ${ }^{67}$ The Four Loves (London: Geoffrey Bles, 1960), 119-20; cf. Reflections, 108, for an attribution of this mythological pattern to ancient pagans.

68 'Christian Apologetics', in God in the Dock (reprinted in Collected Works), 369; cf. 'Religion Without Dogma?", 397, 'the living creator ... if He is at all, must be the God not only of the philosophers, but of mystics and savages, not only of the head and heart, but also of the primitive emotions and the spiritual heights beyond all emotion'. 
for his fiction. It is not for nothing that That Hideous Strength ends with Venus, celestial archon of Perelandra, resting over St. Anne's, with the union of Mark and Jane Studdock restored, and with the departure of Elwin Ransom, made a type of Christ by his combat in Venus with the Unman, for the heavens.

In Lewis's day, however, the 'dying and rising' motif seemed a particularly salient feature of ancient polytheistic religion and mythology, for which the Christian had to offer a satisfactory explanation. Lewis thus made of it the particularly potent imaginative 'praeparatio evangelica' that it had been for him. ${ }^{69}$ The usefulness of that praeparatio is now, after generations of more careful scholarship, much less clear. The well-informed person is more likely to cast doubt on the existence of a 'dying and rising' motif (as I have heard even a Neopagan Classicist do) than try to appropriate it for atheism or Christianity. What, then, becomes of Lewis's apologetic argument from myth? One might try to ease the tension between its aesthetic and historicist elements by doubling down on the former. Being myths in his deep sense of the word, the stories of 'dying and rising' gods hold their power regardless of when, or in what words, they were first told, and in fact similarly interesting parallels can be named from the centuries after Christ, to which the apologist might also appeal. ${ }^{70}$ This, the easy way forward, will not quite do. Lewis, as we have seen, did take for granted the myths' priority, and can imply even that Baldur, who is best known through the twelfth-century mythographies of Snorri Sturluson, belongs with Osiris in primordial antiquity. ${ }^{71}$ From a reader of Frazer, who made Balder the central figure of the last part of the

\footnotetext{
69 'Religion Without Dogma?', 389.

${ }^{70}$ Brazier, 'Christological Prefigurement', 763-4.

${ }^{71}$ On the myth of Balder, see, e.g., Smith, 'When the Bough Breaks', 359-66. Lewis speaks of him (in one breath with Osiris) as 'dying nobody knows when and where', without
} 
third edition of The Golden Bough, this is not a startling move. It does mean, however, that if we choose to focus only on the central thread of Lewis's argument - the imaginative power of the dying-and-rising myth — we will pare away elements to which Lewis did, in fact, hold. We will be developing his argument, not simply representing it.

That development will expose the argument squarely to the vagaries of the individual reader's taste. No longer are we arguing about how to interpret the relationship of one body of ancient literature (the canonical Christian Gospels) to another generally recognized as preceding, resembling, and perhaps influencing it. We are, instead, disputing the emotive and intellectual impact of literature, and cannot take for granted that a modern reader, even one reasonably familiar with ancient mythologies, will show the appreciation of the aesthetic power of the 'dying and rising' myths that so gripped Frazer's early twentieth-century readers. The reasons are several. With the contraction of Classical learning, such stories no longer hold the imaginative power they once did; as told in antiquity, they are often marked by the 'cruelty and obscenity' that Lewis, like Plato, deplored in ancient myths; ${ }^{72}$ above all, Frazer's day has, in some mysterious but ineluctable way, passed, and the fact that his tracing of motifs through the thickets of mythology is not quite true is thus enough to poison the

pointing out that his story postdates Osiris' by millennia ('Myth Became Fact', 343). Lewis also mentions Balder a few lines after the statement about myth as pre-Christian praeparatio in 'Religion Without Dogma?', 389 (quoted above, p. 9).

${ }^{72}$ I quote from Experiment, 42. Though Plato was able, in the allegory of the cave, to invent a story imbued with the power Lewis finds in myth, he found poetry about the gods as 'meaningless and shocking' as Lewis is tempted to (Republic 2, 377a-380d, 7, 514a-518b). 
myth's charm. As Lewis put it, following Owen Barfield, 'our own age is also "a period," and certainly has, like all periods, its own characteristic illusions'. ${ }^{73}$

Lewis himself offers a possible way forward. He remarks in An Experiment in Criticism: 'As I have already said, the degree to which any story is a myth depends very largely on the person who hears or reads it. An important corollary follows. We must never assume that we know exactly what is happening when anyone else reads a book. ${ }^{74}$ In $\mathrm{H}$. Ridder Haggard, the writer of thrillers, Lewis suggests, a boy will find the genuinely mythic, as the same boy would not in John Buchan, governor-general of Canada and part-time novelist. The judgment could be questioned: is Buchan's The Dancing Floor, a tale of impending destiny and of primitive ritual inherited from the mists of Greek antiquity, not properly mythical? It is certainly profoundly Frazerian. Despite his generosity toward other readers, Lewis holds, quite consistently, that some stories are mythic and others are not. Though 'myth' is not a closed set, its contents are nonetheless not determined by individual whim, but by the impact a story is likely to have on its readers - and Lewis believes some will be mythic for nobody (hence the list of synopses which we discussed above). ${ }^{75}$ Yet the conclusion matters more than the examples. If a story's mythic quality depends on the reader, then the apologetic appeal to actual, particular ancient myths of 'dying and rising' gods can be readily dissolved back into a generalized argument from mythic patterns or motifs (where 'myth' means, not 'ancient tale', but the kind of deep story, of whatever age, that moved Lewis so much). One of the attractions of the Gospels, for a certain kind of 'literary' mind, might be (on that argument) that they contain, in what is proposed as historical fact, the

\footnotetext{
${ }^{73}$ Surprised by Joy, 208.

${ }^{74}$ Experiment, 48.

${ }^{75}$ Experiment, 40-1.
} 
patterns of a really weighty story, the kind of thing of which one might say, "I shall never escape this. This will never escape me. These images have struck roots far below the surface of my mind." 76

Such a generalized form of the argument from myth certainly was available to Lewis. Tolkien articulated it in 'On Fairy-Stories', around the same time as the first edition of Miracles. ${ }^{77}$ 'The Gospels', Tolkien says, 'contain a fairy-story, or a story of a larger kind which embraces all the essence of fairy-stories': their aesthetic power, symbolic weight (here Tolkien does not denounce allegory), and above all the 'eucatastrophe', the sudden happy ending, in which Tolkien finds the truest and best sort of 'Fairy-Story' or 'Fantasy'. ${ }^{78}$ Nowhere in this account does Tolkien suggest that some particular kind of mythic story specifically prefigures the Gospels, nor, on a careful reading, did he and Dyson suggest it in their conversation with Lewis in $1931 .{ }^{79}$ There, the argument is not that Baldur, Adonis, and Bacchus reflect the nature of God, but that myths of this kind move Lewis — and so should the Gospel. Tolkien's argument, as he develops it in 'On Fairy-Stories', is that the Gospel is 'fairy-story' supremely, a thing better and greater, as a story, than mere human myths, and true as well. Framed thus, the argument from myth does not rest on the beliefs of ancient polytheists about their gods, but only on the Gospel's being, in its own right, the kind of deep story that Lewis called 'myth' in his special sense.

\footnotetext{
${ }^{76}$ Experiment, 48-49.

${ }^{77}$ In Essays Presented to Charles Williams, 38-89, at 82-4.

78 'On Fairy-Stories', 83.

${ }^{79}$ Quoted above, p. 2.
} 
There are more contacts between Lewis's and Tolkien's ideas that I can explore here, not least in the connection each draws between Gospel and Creation. ${ }^{80}$ The key thing is that Lewis never seems to have formulated a similarly generalized argument himself. His apologetic argument from myth, as he actually developed it, is not a broadly literary case for the aesthetic power and emotional attractiveness of the Gospel. Reliant specifically on the dying-and-rising motif, it is another echo of the colossal impact of The Golden Bough, in which the appreciative can find nothing less than a modern mythology, but a reader less inclined to enchantment will see a farrago of shoddy ethnology and uncritical classicism. ${ }^{81}$ Lewis's apologetic argument from myth stands, therefore, in a position not unlike that of the much grander refutation of the Vergilian legend of Rome in Augustine's City of God. It is a

${ }^{80}$ To Lewis's comments in Miracles, cf. 'On Fairy-Stories, 84, 'For the art of it has the supremely convincing tone of Primary Art, that is, of Creation.'

${ }^{81}$ Lewis observed something similar about Carl Jung's theory of archetypes, in 'PsychoAnalysis and Literary Criticism', in Selected Literary Essays, edited by Walter Hooper (Cambridge: Cambridge University Press, 1969), 286-300, at 297-300. For the positive judgment of Frazer, see, e.g., Herbert Weisinger, who replies to Leach's 'Golden Twig' in 'The Branch That Grew Full Straight', Daedalus 90, no. 2 (1961), 388-99, thus, at 390, 'And I would suggest that the source of power behind this new conception is in each instance the force of that ancient myth and ritual pattern of birth, death, and rebirth, now expressed in terms of the language, the orientation, and the needs of our own times and circumstances, and therefore made freshly relevant. ... Yet, without intending to, each man [Darwin, Marx, Freud, and Frazer] in his own way has been able to work his way back to the ultimate fructifying source of the Western tradition, and, as can happen to reaffirm its message that, in the face of an indifferent, even hostile, universe, man can live, and live meaningfully.' 
product of an intellectual moment now past. It may offer a framework with (if not within) which the cultural critic might think even now about patriotism, myth, and the place of the monuments of ancient Greco-Roman civilization — or Victorian Britain —in the grand scheme of human history. What it will not do is tell us what ancient myths meant to those who told them, who may only, even on Lewis's own view, have glimpsed the truth in shadow.

There are two corollaries. The first is that modern readers eager to appropriate Lewis's arguments must keep in mind his wider conception of myth: one cannot say, without further reflection, that actual ancient myths are stories that reveal truths about God or Creation (still less, that their ancient tellers meant them to be such). To that conviction the individual reader might win, if Lewis is right, by experience of particular stories, but it is not a general feature of everything called 'myth', and Lewis, wisely, does not suggest that it is. His views are, moreover, at odds with those of many of his own authorities. Lewis is often called a Platonist, but Plato did not find, in his people's stories, the deep meaning Lewis could. ${ }^{82}$ Lewis was certainly a Christian apologist, but his ancient counterparts did not, as he well knew, have his regard for stories they considered demonic lies destructive both of real reverence and of properly sober morality. ${ }^{83}$ His ideas are a product of an educational and

${ }^{82}$ Later Platonists did, however: Porphyry of Tyre, for example, wrote an allegorical exposition of Homer's cave of the nymphs (Odyssey 13.103-112).

${ }^{83}$ Reflections, 89 . There were occasional defenses of limited Christian use of mythological works (the most famous Basil's Address to the Youth), but ancient Christians, including Basil himself, ordinarily denounce stories about the gods. That is not, of course, to say that ancient Christians did not continue to find ancient poetry attractive: see especially Sabine MacCormack, Shadows of Poetry: Vergil in the Mind of Augustine (Berkeley: University of California Press, 1998). 
cultural moment, far removed (as is our own) from late antiquity, that may not demand our agreement, unless, of course, we have been convinced from logic and experience that what he says is true. To make a grand theory of mythology would require a careful engagement with ancient appropriations and critiques of myth and, still more, with the sheer, exuberant variety of stories that are passed down in both poetry and prose. Lewis proposed nothing of the kind.

Second, the locus of the mythical moves, if one is going to develop Lewis's arguments as I have suggested, from the ancient into a particular but transhistorical type of story. Frazer's Golden Bough is, or so one could argue, a myth of that kind, expressed in the encyclopaedic learning of a nascent anthropological science. So too, at its best, might modern fiction be, including books outside the 'fantasy' genre that owes much to Lewis and more to Tolkien, but some inside it as well. The appeal of the apologetic argument from myth will then be, to the one who feels the pull of such things, the thought that a story like them-a story with a similarly mythic claim upon the heart and imagination- 'really happened' ${ }^{84}$ That was not the argument Lewis, a lover of ancient myth faced by historicist critics of his religion, did in fact make. It is, however, an argument that could still be made, and that reflects the heart of his convictions more truly than any attempt to revive the argument from the 'dying and rising' of Attis, Osiris, or Balder.

${ }^{84}$ To quote again from the Letter to Arthur Greeves on 18 October 1931, no. 172 in Hooper (ed.), They Stand Together, 427 